\title{
OIISAE \\ EVALUATION OF IMPLEMENTATION OF INCLUSION EDUCATION PROGRAMS IN MADRASAH IBTIDAIYAH BADRUSSALAM SURABAYA
}

\author{
Evi Sopandi \\ Kementerian Agama Republik Indonesia \\ evi_sopandi@yahoo.co.id
}

\begin{abstract}
This study aims to evaluate the inclusive education program at Madrasah Ibtidaiyah (MI) Badrussalam Surabaya. The education program aims to improve human resource competencies in increasing abilities. The evaluation model used in this study is the CIPP model (context, input, process, and product) of the qualitative research approach model introduced by Stufflebeam. The results showed that the education program at MI Badrussalam Surabaya had run well in accordance with the education program that had been prepared. However, in the implementation of inclusive education in MI Badrussalam, there are still some deficiencies both in the fields of funding, facilities and infrastructure as well as on the Welfare of mentors and special teachers (GP / K).
\end{abstract}

Keywords : evaluate, CIPP Model, educational program, MI Badrussalam

whole world has the same view that education can improve a person's socio-economic standard of living, break the chains of poverty and sustain the nation's development process. Not surprisingly, in various parts of the country, scholarship programs are provided for poor families (Cristovam, 2006; Tiedao Zhang, 2006). For example, in Brazil to alleviate poverty by using the Bolsa Escola Program, this program replaces "needs" for schools with "demands" for schools (Cristovam, et al, 2006). Whereas in China, to alleviate the majority of poor people who are scattered in rural areas through the provision of education in the form of courses, and nine-year compulsory education programs (Tiedao Zhang, 2006).

Not much different from Brazil and China, Indonesia also entrusted education as a way out to alleviate poverty. Poverty is one of the factors that hinder a person in accessing education. The equality of getting access to education for the continuity of children's education without recognizing social, economic, political and cultural backgrounds has basically been accommodated in the National Education System Law No. 20 of 2003 article 11 paragraph 1: "The government and regional governments are obliged to provide services and facilities, and ensure the quality of education for every citizen without discrimination". 
Based on the narrative above, it can be concluded that the issue of equal opportunity to gain access to education, especially for some marginalized communities, including those categorized as special needs children (ABK) find the moment in tune with the course of national development. In this context the inclusive education program implemented in the Madrasah Ibtidaiyah (MI) Badrussalam Surabaya seeks to provide education for all groups, including for children who have special needs. In this context MI Badrussalam Surabaya provides educational services for Children with Special Needs, which the educational process requires specific services, different from children in general because they experience obstacles in learning and development.

As an inclusive education program as described above it needs to be evaluated, its success or failure by evaluating the education program to assess the design, implementation, and results that have been achieved from the education program, by providing an accurate analysis of the success or failure of the policy, carried out by the actors implementation of policies. Evaluation of this education program can be useful in providing recommendations on the impact of the implementation of inclusive education to improve further education programs. The evaluation of the education program was strengthened by the evaluation of the implementation program and its recommendations for improving the quality of the implementation of inclusive-based education.

Efforts to conduct an evaluation are important to do. Because the main function of evaluation is to provide correct information data on the implementation of education so that the implementation of education can make the right decision whether the education process will be continued, postponed or not carried out according to Fauzi (Fauzi, 2011: 160). Therefore, education evaluation functions as an effort to (Fauzi, 2011: 167): (a) determine the level of progress in implementing education; (b) find factors driving and inhibiting the implementation of education; (c) find irregularities or mistakes in the implementation of education; and (d) obtain material for the preparation of suggestions for improvement, change, termination, or expansion of education.

Based on the explanation above, the author believes that the evaluation of educational programs in MI Badrussalam Surabaya is very important to do. This aims to make improvements to the educational program going forward so that it is more effective. From this conclusion the author decided to conduct a study entitled: "Evaluation of the Implementation of Inclusion Education Programs in Ibtidaiyah Badrussalam Madrasah Surabaya"

\section{METHOD}

Research uses the CIPP program evaluation model (Context, Input, Process and Product) introduced by Stufflebeam (Stufflebeam, et al, 2013: 1314). The study was conducted at MI Badrussalam Surabaya. Data collection 
techniques include interviews, observation and document study (primary and secondary data). Meanwhile, data analysis was carried out since the beginning of the research and throughout the research process. The data obtained is then collected for systematic processing. Starting from observation, editing, classifying, reducing, then the activity of presenting data and concluding data. Data analysis techniques in this study used interactive analysis techniques from Miles and Huberman (1992: 16).

\section{RESULTS}

Evaluation of inclusive education programs in MI Badrussalam Surabaya using the CIPP model. This model was first developed by Stufflebeam and Guba in 1968. The Stufflebeam model is also called the CIPP model, which is short for Context, Input, Process, and Product. This model can in principle be used for program evaluation and educational outcomes. Stufflebeam argues that the important purpose of evaluation is not to prove but to improve (Stufflebeam and Shinkfield, 2007: 325-358; Fitzpatrick, Sanders, and Worthen, 2004: 89-92; Alkin (Ed), 2004: 245-251).

The results of this study indicate that the standard evaluation criteria of context components, input components and process components that have been established in this study have been well achieved. However, the standard criteria for evaluating product components that have been set in this study are only partially achieved, some are not yet known because the results have never been done. For clarity, by referring to the purpose of this study, the results of the study can be described in more detail below:

\section{Context Evaluation Results (context)}

The context evaluation includes an analysis of the initial conditions (background of the establishment of the institution, legal basis, and general policy formulation) of education in MI Badrussalam Surabaya. Inclusive Education Program in MI Badrussalam Surabaya as one form of educational programs to develop HR potential will not be separated from that context. The following is a narrative explanation.

\section{a. Background of the holding of education MI Badrussalam Surabaya}

It is undeniable that religious-based educational institutions were once underestimated by the community. This is based on the image of religious education institutions that only pursue religious knowledge in an-sich (Ahmad, 2012: 39). So that religious-based educational institutions seem to be left behind in terms of developing science. In the present context, this view is no longer relevant to assess the existence of religious based educational institutions. 
Therefore, religious-based education, especially Islamic-based educational institutions have changed the image of modern and quality education. For example the emergence of leading religious-based schools in Indonesia (borrowing the term Azra Muslim elite school) in the 90s as a quality school because it succeeded in repositioning the role of Islamic education from an orientation to Islamic sciences to an educational institution that orientates its education towards mastery and science achievement knowledge and technology (Azra, 2012: 83).

The growth of religious-based educational institutions in Indonesia does not only depend on quantity. However, the growth of religious-based educational institutions is also accompanied by the development of the quality of the education process. In the present context many educational institutions offer various educational programs, including inclusive education programs for the community. Like the inclusive education program provided by Madrasah Ibtidaiyah Badrussalam in Surabaya. Historically Madrasa Ibtidaiyah (MI) Badrussalam was established and operating since 1997. Institutionally the management of MI Badrussalam is under the auspices of the Kalikendal Pradah Mosque Foundation. At present MI Badrussalam is led by Nur Fatmah, S.Pd. Administratively, MI Badrussalam is located at Jalan HR Muhammad 161 Surabaya. The position of MI Badrussalam is very strategic, safe and comfortable, can be reached by public transportation, is near densely populated settlements, close to health services, and is in the administrative center of the Pradah Kalikendal Kelurahan Office and the Dukuh Pakis District Office within $10 \mathrm{~km}$ from the government center city of Surabaya. So that the Madrasah Ibtidaiyah Badrussalam is exactly the goal and choice of the community to send their children to school.

\section{b. The legal basis for the policy administration Surabaya MI Badrussalam}

\section{1. juridical Platform}

Providing access to education for children with special needs is a mandate contained in the 1945 Constitution of the Republic of Indonesia Article 31 , paragraph 1 , of the rights and obligations of citizens to obtain education. Then access to education for children with special needs is also stated expressly in Law Number 20 Year 2003 Chapter IV article 5 paragraph 1 that every citizen has the same right to obtain quality education. The juridical foundation of MI Badrussalam in organizing inclusive education is explained in the following

a. Act Number 35 of 2014 concerning Child Protection;

b. Law Number 8 of 2016 concerning Persons with Disabilities;

c. Government Regulation Number 17 of 2010 concerning Management and Implementation of Education as amended by 
Government Regulation Number 66 of 2010 concerning Amendment to Government Regulation Number 17 of 2010 concerning Management and Implementation of Education;

d. Government Regulation Number 19 of 2005 concerning National Education Standards as amended;

\section{The philosophical foundation The}

application of inclusive education in Indonesia is Pancasila which is a five pillar as well as ideals which are founded on a more fundamental foundation, called Bhineka Tunggal Ika (Abdulrahman, 2003). This philosophy is a form of acknowledgment of human diversity, both vertical and horizontal diversity, which carries a single mission as God's people on earth. Vertical diversity is characterized by differences in intelligence, strength, physical, financial ability, rank, ability to control themselves, etc. Whereas horizontal diversity is characterized by differences in ethnicity, race, language, culture, religion, residence, political affiliation, etc. Although diverse, but with the similarity of missions carried on this earth, it becomes an obligation to build togetherness and interaction based on mutual need.

In this case, Islam as a religion of "book religion", the Qur'an also calls itself a book (book). Literacy is emphasized, even the first word spoken by Archangel Gabriel in about $610 \mathrm{AD}$ to the Prophet Muhammad is iqra '!. According to Al-Attas (1979), Islamic education is based on an ontological basis that the world itself is valueless. The Qur'an gives a normative perspective while the Sunnah of the Prophet Muhammad through patterns and models applies Islam rahmatan lil al-'alamin in reading and managing the life of the world which is filled with the temptations of Satan. For this reason, children's development requires education, training, and continuous habituation, from the womb to the grave.

\section{Empirical Basis The}

implementation of inclusive education in madrasas under the Ministry of Religion has been ongoing since 2008, but it was only in 2013 that the Ministry of Religion began developing policies on the implementation of inclusive education in madrasas. In 2015-2016 there were 22 madrasas from the provinces of East Java, Central Java, South Sulawesi, West Nusa Tenggara (NTB) and Banten which were designated as organizing inclusive education.

From the madrassas appointed as providers of inclusive education, data obtained that there were students with special needs, both those who entered before the appointment as a piloting madrasa and who registered themselves after the appointment. 
Madrasas have experiencepractical on how to organize inclusive education. Welcoming with this experience, then there was encouragement from both the Ministry of Religion internally and from outside parties so that the Ministry of Religion could expand the implementation of inclusive education programs in madrasas, because the fact that the existence of students with special needs (PDBK) was not only found in 22 madrasas that became pilots alone, but in other madrassas some also have received PDBK.

In addition, $\mathrm{ABK}$ students (Ananda Rizki Nanda) who have joined MI Badrussalam, before MI Badrussalam provides inclusive learning services also underlie MI Badrussalam to carry out maximum inclusive learning services.

Based on the juridical, philosophical and empirical basis above it is quite clear as a legal umbrella for providing opportunities for Children with Special Needs (ABK) to access education as children are born normally. Here the madrasa is obliged to organize inclusive education. MI Badrussalam, who is piloting inclusive madrassas, provides inclusive education by providing services for students with special needs (ABK), provision of resource space, Special Teacher / GPK, curriculum adjustment, procurement of tools and learning media for ABK, psychological services, etc. . But despite the readiness of MI Badrussalam there are still many things that are lacking in providing services for $\mathrm{ABK}$ such as the availability of adequate infrastructure according to the needs of $\mathrm{ABK}$, the lack of GPK, and the human resources of educators and education personnel related to inclusive education programs is still lacking.

\section{c. Formulation General PolicyofEducation MI BadrussalamSurabaya}

To realize quality education MI Badrussalam Surabaya has a vision, mission and educational goals that are contextual with social developments and changes, both local, national and global. Here MI Badrussalam Surabaya has the following vision and mission:

Vision:

- To become a national standard Madrasa that is capable of producing independent,

Achievement, Islamic Personality, and Environmental insight.

\section{Mission:}

- Prepare prospective future leaders who master science and technology, have a high fighting power, innovative and creative.

- Organizing education effectively so that students develop optimally.

- Organizing learning to foster active, creative and innovative thinking skills.

- Organizing self-development so that students can develop according to their interests and talents.

- Cultivating the environment and religious behavior so students can practice and live their religion significantly. 
- Developing commendable behavior and real practice so students can be role models for their friends and community.

- Providing inclusive and environmentally friendly education

From the above vision and mission narratives, it is expected that the MI Badrussalam Surabaya educational institution will be able to achieve its educational goals. In general, the formulation of educational objectives in MI Badrussalam Surabaya aims to provide basic knowledge as an increase in religious knowledge and skills acquired in Ibtidaiyah madrassas to develop their lives as Muslim individuals, community members and citizens according to their level of development. While the specific objectives of education at MI Badrussalam Surabaya are: 1). Realizing Madrasah Ibtidaiyah as a preaching institution that is in demand by the surrounding community. 2). Improving the quality of MI Badrussalam through integrated curriculum. 3). Improving the quality of students in the academic and non-academic fields. 4). Provide learning skills and life skills, worship habits and noble morals and good learning. 5). Fostering the capacity and potential of students according to their talents and interests. 6). Having the basics of knowledge, abilities, and skills to continue education at a higher level. 7). Increase student competitiveness in the global era. 8). Facilitating the growth and development of Children with Special Needs $(\mathrm{ABK})$ with academic services, compensatory services, fair social interaction and humane communication

\section{Results of Input Evaluation}

In the PPDB process at MI Badrussalam, identification and assessment of students including the socialization of the Inclusive Education Program to related parties in this case is the guardian of students is needed in order to form the same perception between madrasas and guardians of students. Student guardians are expected to be able to recognize the process of learning development of their children and be able to support the implementation of inclusive learning in madrasas, so that parents who have ABK do not get discouraged / shut down and for guardians students regular children can be more grateful and instill the character of tolerance in their children. .

Then fill in the curriculum vitae of students by the guardians of students needed by psychologists as supporting data to identify all students whose results are expected to help the learning planning process that suits each student's needs.

The next stage was carried out by expert Psychological Tests, Initial Identification, Assessment, Advanced Assessment, and Formulation of ABK Profile. The whole series is carried out to optimize the services of inclusive education to students. 


\section{Results of the Process Evaluation}

After the preparation of the ABK learners profile, the MI Badrussalam inclusion team made a compilation of ABK activities which included; Making PPI and RPP by GPK, subject teachers, and class teachers who have ABK students. HR development that handles ABK (Workshops, seminars, internships) at the resource center, Parenting, Home Visit Program for ABK students with problems, conducting midterm and end of semester assessments, as well as compiling report cards.

The curriculum applied at MI Badrussalam in the 2018/2019 school year is 2013 curriculum (K-13) in accordance with KMA Number 117 of 2014 concerning the Implementation of the 2013 Curriculum, everything related to the curriculum is set in document 1 MI Badrussalam curriculum, including curriculum adjustments for ABK namely Duplication, Modification, Substitution and Omission. The implementation process of learning for $\mathrm{ABK}$ students contains four components namely Regular (R), Pull Out (PO), and Assistance (D), and Learning Therapy (TP).

The operational funding sources for MI Badrussalam are obtained from BOS Funds, Bopda Grants, and the participation of student guardians which are partly allocated to inclusive education programs.

The start of the formation of an inclusive education program in MI Badrussalam was the existence of Australia-Indonesia partnership (AEPI) grant funding assistance bridged by MDC in 2015. Funds given to madrassas of 20 million were used for spending on learning media, purchasing $\mathrm{ABK}$ learning resource books and teachers, resource room equipment, psychological testing services, and curriculum preparation process.

In 2016 there was a social assistance program from UNSURI tertiary institutions totaling 10 million for mentoring activities in the process of making PPI and RPP for ABK and GPK apprenticeship activities and several inclusion teams to the source center, one of the inclusive SDNs in Surabaya.

Although the assistance program from AEPI and UNSURI has not been extended, MI Badrussalam remains committed to continuing the inclusive education program. Continue to provide services to $A B K$ even with full limitations, especially in terms of funding.

\section{Evaluation Results Product(product)}

\section{Academic Achievement}

From the results of the identification of ABK students in MI Badrussalam the majority are students who have learning difficulties, even at the beginning of their entry they cannot read, write and count. With the guidance of the special tutor and the implementation of the learning process which consists of regular classroom processes, assisted, pull out and therapy, there are currently many 
students who experience an increase in the academic field, especially in reading, writing and arithmetic. However, until now there has not been much competition in the academic field that has been held for MI ABK students at the sub-district or city level. This makes the academic potential of students less honed.

\section{Achievement Non Academic}

ABK MI Badrussalam students also take part in self-development activities in madrasas. Personal development activities carried out are usually carried out on Fridays. These activities are activities that develop non-academic potential of students, such as making skills, singing, reading poetry, etc. In addition, ABK students, Badrussalam, once took part in a singing competition held by PSLPD UNESA which had the theme of disability day, but had not yet won.

\section{CONCLUSIONS AND RECOMMENDATIONS}

The results of this study indicate that inclusive education at MI Badrussalam has been held since 2016. MI Badrussalam has 7 students with special needs. The implementation of inclusive learning in MI Badrussalam uses the curriculum namely K13. The implementation process of learning for ABK students contains four components namely Regular (R), Pull Out (PO), and Assistance (D), and Learning Therapy (TP). Special Guidance Teacher (GPK) at MI Badrussalam there is 1 GPK, the identification of children with special needs is carried out for five purposes, namely: (1) screening ((2), (2) outsourcing (referral), (3) classification, (4) learning planning, and (5) monitoring learning progress. Curriculum for ABK, including: Duplication means to imitate or duplicate, Modification means to change to be adjusted. Modification of curriculum for students with special needs, Substitution which means replacing, Omission means eliminating. The assessment model adjusts to the curriculum that has been adapted for ABK students: 1). Rating Adjust Time, 2). Adjusting the Assessment Method, 3). Rating Adjusting Content. The results of these conclusions make this research recommendations are as follows:

1. Policy makers are expected to review the regulation of the burden of GPK hours which are only recognized 6 hours per week, in GPK sympathies must have the main task as a teacher in the field of study. GPK should not need to be burdened with other tasks so that they can focus on their duties as GPK.

2. The government needs to make guidelines and rules about Examination and diploma format for $\mathrm{ABK}$.

3. It needs support from the government infrastructure, because the existing facilities and infrastructure still do not meet the needs of ABK so that it can affect $\mathrm{ABK}$ learning. 
4. Ministry of Religion must monitor and participate in delivering ABK graduates to continue to higher levels of education (MTs. Inclusion)

5. City / Province / Central Government needs to determine financing standards for implementing inclusive education

6. The City / Province / Central Government needs to provide training, guidance, and ongoing assistance related to inclusive education

7. City / Province / Central Government needs to use data on the implementation of inclusive education in madrasas as a basis for policy making.

8. GovernmentEmbrace higher education under the auspices of the Ministry of Education and Culture to create special education majors that will later produce graduates who are competent in the special education sector for special needs so that they can be supervised Teachers Specifically (GPK).

9. There is a need for monitoring and evaluation from the center for madrassas to organize inclusive education from the Ministry of Religion and the center.

10. Funding assistance from the central government for infrastructure, construction of buildings and environment friendly with disabilities, fulfillment of infrastructure facilities that support inclusive education programs.

11. Grants for Regular Teachers who work on Curriculum Modifications and inclusive lesson plans that are adjusted to ABK abilities.

\section{REFERENCES}

Daniel L. Stufflebeam, Lori A Wingate, and Thomas Kellagen ,. International Handbook of Educational Evaluation Part One: Perspectives (London: Kluwer Academic Publisher, 2013).

Miles, Mathew B. And A. Michael Huberman, Translators, Tjetjep Rohendi Rosidi. Qualitative Data Analysis (Jakarta: University of Indonesia, UI Press, 1992).

A. Fauzi, Ikka Kartika, Managing Participatory Training (Bandung: Alfabeta, 2011).

Ahmad Ali Riyadi, Islamic Boarding School in the Frame of Political Bureaucracy of Islamic Education in Indonesia, Vol. 23 No.1 January 2012

Alkin, Marvin C. (Ed). 2004. Evaluation Roots: Tracing Theorists' Views and Influences. California, London, New Delhi: Sage Publications.

Stufflebeam, Daniel L. and Anthony J. Shinkfield. 2007. Evaluation Theory, Models, and Applications. San Francisco: Jossey-Bass A Wiley Imprint. 
Fitzpatrick, Jody L., James R. Sanders, and Blaine R. Worthen. 2004. Program Evaluation: Alternative Approaches and Practical Guidelines, Third Edition. Boston: Pearson Education.

Tiedao Zhang and Zhao Minxia, 2006. Universalizing Nine-Year Compulsory Education for Poverty Reduction in Rural China.Source: International Review of Education / Internationale Zeitschrift für Erziehungswissenschaft / Revue Internationale de l'Education, Vol. 52, No. 3/4, Education and Poverty Reduction (May, 2006), pp. 261-286 Published by: Springer Stable URL: http://www.jstor.org/stable/29737080

Cristovam Buarque, Vida A. Mohorčič Špolar and Tiedao Zhang, 2006. Introduction: Education and Poverty Reduction. Source: International Review of Education / Internationale Zeitschrift für Erziehungswissenschaft / Revue Internationale de l'Education, Vol. 52, No. 3/4, Education and Poverty Reduction (May, 2006), pp. 219-229 Published by: SpringerStable URL: http: // www. jstor.org/stable/29737077.

Azra, Azyumardi. 2012. Islamic Education: Tradition and Modernization in the Middle of the Third Millennium Challenge. Jakarta: Kencana Prenada Media Group. 